\title{
Virtual Link Aggregation Network Performance Using MikroTik Bonding
}

\author{
Firmansyah ${ }^{1}$, Mochamad Wahyudi ${ }^{2}$, Rachmat Adi Purnama ${ }^{3}$ \\ Sistem Informasi Sekolah Tinggi Manajemen Informatika dan Komputer \\ Nusa Mandiri Jakarta (STMIK Nusa Mandiri Jakarta) ${ }^{1}$ \\ Teknologi Informasi Universitas Bina Sarana Informatika ${ }^{23}$ \\ Jakarta, Indonesia \\ e-mail: firmansyah.fmy@nusamandiri.ac.id ${ }^{1}$ wahyudi@bsi.ac.id² ${ }^{2}$ Rachmat.rap@bsi.ac.id ${ }^{3}$
}

To cite this document:

Firmansyah, F., Wahyudi, M., \& Purnama, R. A. (2020). Virtual Link Aggregation Network Performance Using MikroTik Bonding. IAIC Transactions on Sustainable Digital Innovation (ITSDI), 2(2), 130-138.

DOI : https://doi.org/10.34306/itsdi.v2i2.394

\begin{abstract}
Quality of Service in a network is a big thing that must be resolved and dealt with as best as possible. The limitation of the maximum transfer rate in network devices creates an obstacle in the process of transferring data packets. To maximize the transfer rate in network devices, you can use Virtual Link Aggregation which can offer bandwidth optimization and failover in the network. Link aggregation is a solution in combining several physical links into one logical link. The method used in this research is to consider the allocation of bandwidth, load balancing and failover in the link aggregation. From the results of the link aggregation test using two (2) interface bonding, the results of the bandwidth averages when there is a UPD data packet transfer to 0 bps / 184.9 Mbps, which was previously around 0 bps / $91.6 \mathrm{Mbps}$. While the result of the bandwidth averages when the TCP data packet transfer occurs is 0 bps / 105.5 Mbps, which was previously around 0 bps / 93.8 Mbps. Link Aggregation using a Mikrotik Router is a solution to produce a larger Throughput Bandwidth by combining two (2) Ethernet Physical Links into one logical link.
\end{abstract}

Key Word: Link Aggregation, Bandwidth, Quality of Service, Physical Link, Logical Link 


\section{Introduction}

Stability and reliability of Quality of Service in a network now seems to be a big thing that must be resolved and dealt with as best as possible. Speed in transferring data is a top priority at this time. To increase bandwidth in the network, you can use the link interface merging technique or more familiarly known as the Link Aggregation (LAG) technique [1]. The use of the Link Aggregation Control Protocol (LACP) protocol was then adopted and developed by one of the MikroTik computer network vendors with the name MikroTik Bonding and regulated by the IEEE 802.3ad standard [2]. By using Link Aggregation, it is expected to reduce QoS failures on a network. Link Aggregation itself is a method used to combine more than one interface in order to get a greater bandwidth speed [3], and the use of Link Aggregation can increase the speed of data packet transfer in the network to be twice or more than the previous speed [4] link aggregation is a method for building bandwidth connections using logical links that include a number of physical links [5]. Link aggregation forms a virtual link group by combining several interfaces into one [6] so as to form load balancing in distributing physical workloads [7]. The use of Link Aggregation in previous studies was able to reduce the occurrence of throughput, delay and downtime [8] ], and can improve network quality when viewed from the delay, jitter or throughput [9] [10] [11].

Link aggregation combines several physical interfaces into logical links that can be used to increase bandwidth in the network and is able to prevent link failure [12], as protection / backup link in case of link failure on one of the links and can also increase link capacity [13] ]. Link aggregation is needed in implementing load balancing and when a link is in an overloaded state some of its traffic will be channeled to other links [2] [14].

\section{Research Method}

In the Link Aggregation Bonding Performance Analysis research, researchers used the help of two (2) MikroTik 951HAP-Lite RouterBoard devices using RouterOS version 4 and using 5 laptops and using Colasoft Capsa 11 network monitoring software which is used to determine the data packet transfer process when using Aggregation link.

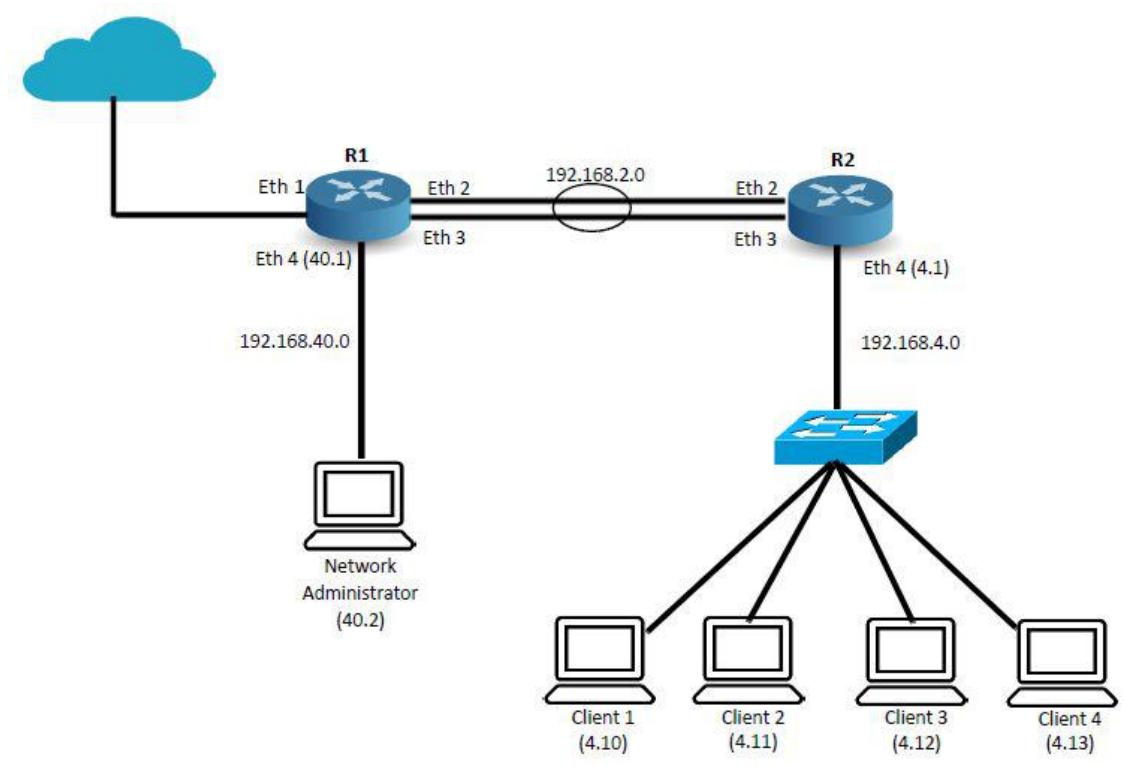


Figure 1. Network Schematic

TABEL 1. Spesifikasi IP Address

\begin{tabular}{|c|c|c|}
\hline Devic & Interface & IP Address \\
\hline \multirow{3}{*}{$\begin{array}{l}\text { Route } \\
\text { r } 1\end{array}$} & $\begin{array}{l}\text { Ether } 1 \\
\text { Ether } 2\end{array}$ & DHCP Client \\
\hline & Ether 3 & 192.168.2.1 \\
\hline & $\begin{array}{l}\text { Bonding } \\
\text { Ether } 4\end{array}$ & 192.168.40.1 \\
\hline \multirow[t]{2}{*}{ Router 2} & $\begin{array}{l}\text { Ether } 2 \\
\text { Ether } 3 \\
\text { Bonding }\end{array}$ & 192.168.2.2 \\
\hline & Ether 4 & 192.168.4.1 \\
\hline
\end{tabular}

Described in Figure 1 and table 1 is the network scheme and IP Address specifications used in the Link Aggregation Bonding Performance Analysis research. Router 1 and Router 2 will perform Link Aggregation Bonding to interfaces Ether2 and Ether3.

\section{Findings}

1. Bandwidth Testing Scenarios Without Bonding

The first test scenario is to test the connectivity to determine the performance in the network before implementing Link Aggregation Bonding. Seen in Figure 2 and Figure 3 are the results of network connectivity tests without using Link Aggregation Bonding.

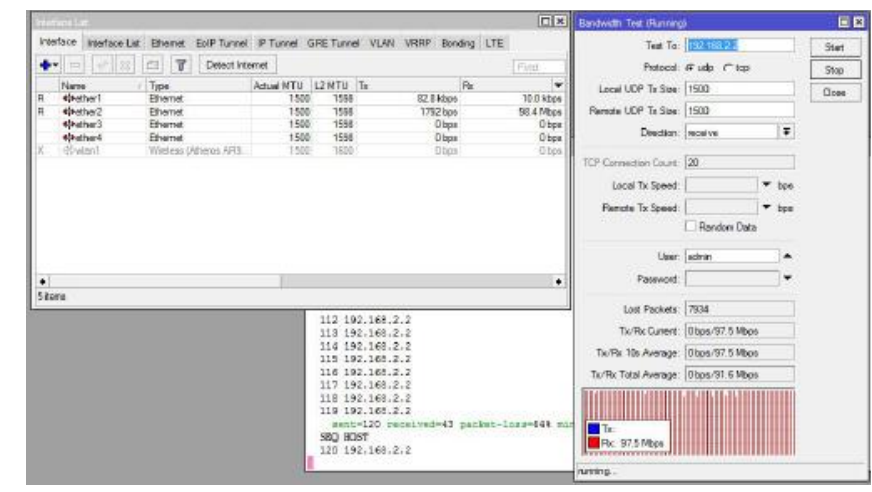

Figure 2.UDP Connectivity Test Without Bonding

Described in Figure 2 is a data packet transfer process when using 1 line interface with UPD protocol data packet transfer from router to client of Tx / Rx Total Average of $0 \mathrm{bps} /$ 91.6 Mbps. 


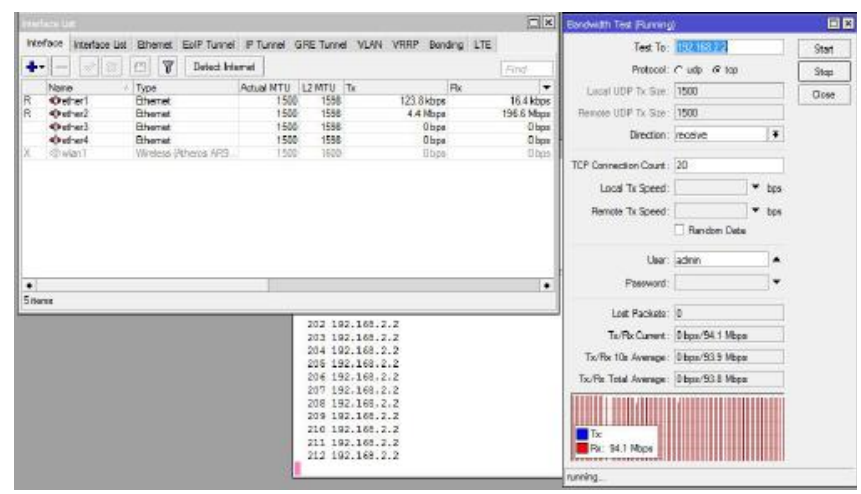

Figure 3. Test the TCP Connectivity Without Bonding

Meanwhile, described in Figure 3, is the result of the bandwidth connectivity test of the TCP protocol from the router to the client with a Tx / Rx Total Average of $0 \mathrm{bps} / 93.8 \mathrm{Mbps}$.

2. Bandwidth Bonding Testing Scenarios

The connectivity test then tests the bandwidth in the process of transferring data packets for the UDP Protocol and TCP Protocol between Router 1 to Router 2. Seen in Figure 4 and Figure 5 are the test results after implementing Link Aggregation Bonding on the MikroTik Router. Previously, the data packet transfer process used only 1 link interface with a Tx / Rx Total Average bandwidth of $0 \mathrm{bps} / 91.6 \mathrm{Mbps}$ for UDP data packet transfer processes and Tx / Rx Total Average of 0 bps / 93.8 Mbps for TCP data packet transfer processes. After the implementation of the MikroTik Link Aggregation Bonding, the bandwidth in transferring UPD and TCP data packets will increase 2 times from before.

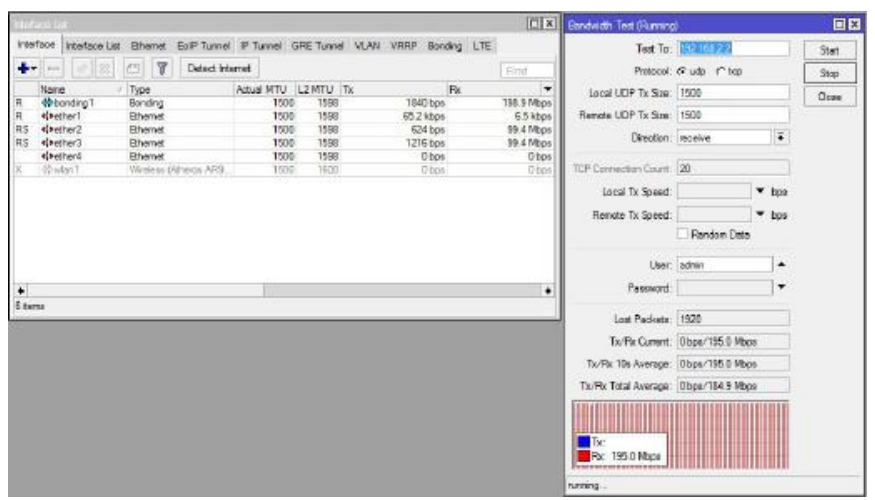

Figure 4. UDP Bonding Connectivity Test

Described in Figure 4 is the bandwidth allocation obtained when transferring data packets. at 0 bps / 105.5 Mbps. Bandwidth allocation will continue to increase if there are additional interfaces in the MikroTik Link Aggregation Bonding. 


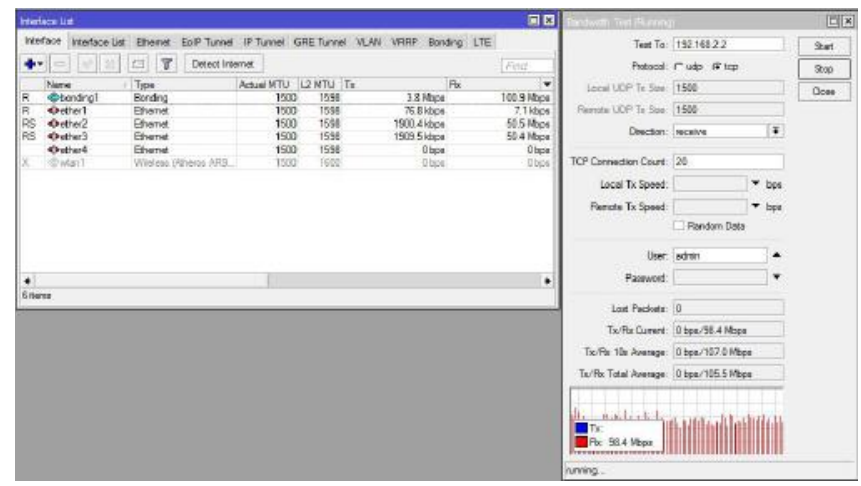

Figure 5. TCP Bonding Connectivity Test

3. Load Balancing Bonding Testing Scenarios

The next test is to test the connectivity on the load balancing performance that occurs when implementing link aggregation bonding. The load balancing test is used to determine the performance of each interface in the implementation of Link Aggregation Bonding whether each of these interfaces can share traffic in the network equally. Seen in Figure 6 is a load balancing connectivity test in the implementation of link aggregation bonding mikrotik. The connectivity test is carried out from the Network Administrator computer to the client that has the IP address 192.168.4.10 located on Router 2 by going through route gateway router 1 with the allocation of the ip address 192.168.2.1 and heading to router 2 with the allocation of the ip address 192.168.2.2.

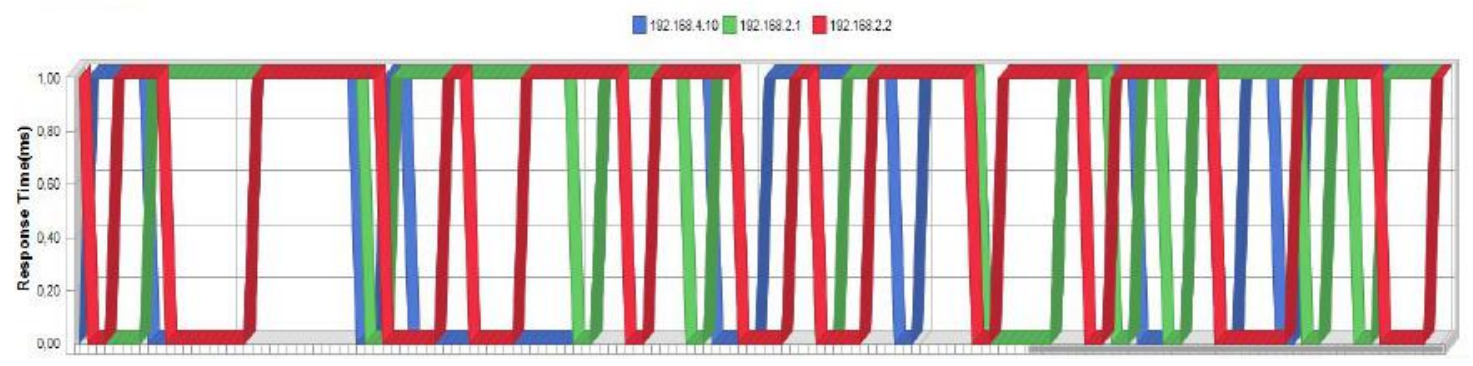

TABEL 3.Failover Bonding

\begin{tabular}{|c|c|c|c|}
\hline Monitoring Name & Ether2 & Ether3 & Bonding \\
\hline rx-packets-per-secon & 5 & 0 & 5 \\
\hline rx-bits-per-second & $\underset{\mathrm{s}}{3.6 \mathrm{kbp}}$ & Obps & $3.6 \mathrm{kbps}$ \\
\hline $\begin{array}{c}\text { fp-rx-packets-per } \\
- \\
\text { second }\end{array}$ & 4 & 1 & 5 \\
\hline fp-rx-bits-per-second & $\begin{array}{c}2.6 \mathrm{kbp} \\
\mathrm{s}\end{array}$ & Obps & $3.5 \mathrm{kbps}$ \\
\hline rx-drops-per-second & 0 & 0 & 0 \\
\hline rx-errors-per-second & 0 & 0 & 0 \\
\hline tx-packets-per-secon & $26 \mathrm{khn}$ & 0 & 5 \\
\hline
\end{tabular}




\begin{tabular}{cccc} 
fp-tx-packets-per & s & 0 & 0 \\
- & 3 & & \\
second & & & \\
fp-tx-bits-per-second & $\begin{array}{c}2.0 \mathrm{kbp} \\
\mathrm{s}\end{array}$ & $0 \mathrm{bps}$ & $0 \mathrm{bps}$ \\
tx-drops-per-second & 0 & 0 & 0 \\
tx-queue-drop-pe \\
r- & 0 & 0 & 0 \\
$\begin{array}{c}\text { second } \\
\text { tx-errors-per-second }\end{array}$ & 0 & 0 & 0 \\
\hline
\end{tabular}

Tabel 4.Packet Loss Bonding

\begin{tabular}{|c|c|c|c|c|c|c|}
\hline $\begin{array}{c}\begin{array}{c}\text { Percob } \\
\text { aan } \\
\mathrm{Ke}\end{array} \\
\end{array}$ & $\begin{array}{l}\text { Packe } \\
\mathbf{t} \\
\text { Send } \\
\end{array}$ & $\begin{array}{l}\text { Packet } \\
\text { Receiv } \\
\text { er }\end{array}$ & $\begin{array}{l}\text { Pack } \\
\text { et } \\
\text { Loss } \\
\end{array}$ & $\begin{array}{l}\text { Tim } \\
\text { e } \\
\text { Min }\end{array}$ & $\begin{array}{l}\text { Tim } \\
\mathbf{e} \\
\operatorname{Max} \\
\end{array}$ & $\begin{array}{c}\text { Time } \\
\text { Avera } \\
\text { ge } \\
\end{array}$ \\
\hline 1 & 55 & 55 & 0 & $\underset{\mathrm{s}}{\mathrm{Om}}$ & $\underset{\mathrm{s}}{1 \mathrm{~m}}$ & Oms \\
\hline 2 & 67 & 67 & 0 & $\begin{array}{c}1 \mathrm{~m} \\
\mathrm{~s}\end{array}$ & $\begin{array}{c}1 \mathrm{~m} \\
\mathrm{~s}\end{array}$ & Oms \\
\hline 3 & 82 & 82 & 0 & $\begin{array}{c}0 \mathrm{~m} \\
\mathrm{~s}\end{array}$ & $\begin{array}{c}1 \mathrm{~m} \\
\mathrm{~s}\end{array}$ & Oms \\
\hline 4 & $\begin{array}{c}12 \\
6\end{array}$ & $\begin{array}{l}12 \\
6\end{array}$ & 0 & $\begin{array}{c}0 \mathrm{~m} \\
\mathrm{~s}\end{array}$ & $\begin{array}{c}1 \mathrm{~m} \\
\mathrm{~s}\end{array}$ & Oms \\
\hline 5 & $\begin{array}{c}13 \\
7\end{array}$ & $\begin{array}{c}13 \\
7\end{array}$ & 0 & $\begin{array}{c}0 \mathrm{~m} \\
\mathrm{~s}\end{array}$ & $\begin{array}{c}1 \mathrm{~m} \\
\mathrm{~s}\end{array}$ & $0 \mathrm{~ms}$ \\
\hline 6 & $\begin{array}{c}14 \\
3\end{array}$ & $\begin{array}{c}14 \\
3\end{array}$ & 0 & $\begin{array}{c}1 \mathrm{~m} \\
\mathrm{~s}\end{array}$ & $\begin{array}{c}1 \mathrm{~m} \\
\mathrm{~s}\end{array}$ & Oms \\
\hline 7 & $\begin{array}{c}21 \\
3\end{array}$ & $\begin{array}{c}21 \\
3\end{array}$ & 0 & $\begin{array}{c}1 \mathrm{~m} \\
\mathrm{~s}\end{array}$ & $\begin{array}{c}1 \mathrm{~m} \\
\mathrm{~s}\end{array}$ & Oms \\
\hline 8 & $\begin{array}{c}22 \\
7\end{array}$ & $\begin{array}{c}22 \\
7\end{array}$ & 0 & $\begin{array}{c}0 \mathrm{~m} \\
\mathrm{~s}\end{array}$ & $\begin{array}{c}1 \mathrm{~m} \\
\mathrm{~s}\end{array}$ & Oms \\
\hline 9 & $\begin{array}{c}24 \\
1\end{array}$ & $\begin{array}{c}24 \\
1\end{array}$ & 0 & $\begin{array}{c}0 \mathrm{~m} \\
\mathrm{~s}\end{array}$ & $\begin{array}{c}1 \mathrm{~m} \\
\mathrm{~s}\end{array}$ & $0 \mathrm{~ms}$ \\
\hline 10 & $\begin{array}{c}27 \\
2 \\
\end{array}$ & $\begin{array}{c}27 \\
2 \\
\end{array}$ & 0 & $\begin{array}{c}1 \mathrm{~m} \\
\mathrm{~s}\end{array}$ & $\begin{array}{c}1 \mathrm{~m} \\
\mathrm{~s}\end{array}$ & $0 \mathrm{~ms}$ \\
\hline
\end{tabular}

Described in Figure 6 and Table 2 are the results of the load balancing connectivity test in implementing Link Aggregation Bonding. Each ether 2 interface and ether 3 interface can function properly and the bonding interface is the cumulative result of combining the bandwidth available from the ether 2 and ether 3 interfaces.

4. Failover Bonding Testing Scenarios

The Link Aggregaton performance test does not escape the Failover test in it. Failover will occur automatically if one of the interfaces used in Link Aggregation Bonding experiences a failed link. Described in table 3 is a failover that occurs in the network link aggregation bonding Mikrotik, if the previous test results in table 2 show that the two ethernet interfaces used can transfer data packets. now only ether 2 interface can 
transfer data packets.

TABEL 3.

Failover Bonding

\begin{tabular}{|c|c|c|c|}
\hline Monitoring Name & Ether2 & Ether3 & $\begin{array}{c}\text { Bondin } \\
\mathbf{g}\end{array}$ \\
\hline $\begin{array}{c}\text { rx-packets-per-seco } \\
\text { nd }\end{array}$ & 5 & 0 & 5 \\
\hline rx-bits-per-second & $3.6 \mathrm{kbps}$ & Obps & $3.6 \mathrm{kbps}$ \\
\hline $\begin{array}{l}\text { fp-rx-packets-per-s } \\
\text { econd }\end{array}$ & 4 & 1 & 5 \\
\hline $\begin{array}{c}\text { fp-rx-bits-per-secon } \\
\text { d }\end{array}$ & $2.6 \mathrm{kbps}$ & Obps & $3.5 \mathrm{kbps}$ \\
\hline $\begin{array}{c}\text { rx-drops-per-secon } \\
\text { d }\end{array}$ & 0 & 0 & 0 \\
\hline $\begin{array}{c}\text { rx-errors-per-secon } \\
\text { d }\end{array}$ & 0 & 0 & 0 \\
\hline $\begin{array}{c}\text { tx-packets-per-seco } \\
\text { nd }\end{array}$ & 5 & 0 & 5 \\
\hline tx-bits-per-second & $3.6 \mathrm{kbps}$ & Obps & $3.6 \mathrm{kbps}$ \\
\hline $\begin{array}{l}\text { fp-tx-packets-per-s } \\
\text { econd }\end{array}$ & 3 & 0 & 0 \\
\hline $\begin{array}{c}\text { fp-tx-bits-per-secon } \\
d\end{array}$ & $2.0 \mathrm{kbps}$ & Obps & Obps \\
\hline $\begin{array}{c}\text { tx-drops-per-secon } \\
\text { d }\end{array}$ & 0 & 0 & 0 \\
\hline $\begin{array}{l}\text { tx-queue-drop-per-s } \\
\text { econd }\end{array}$ & 0 & 0 & 0 \\
\hline $\begin{array}{l}\text { tx-errors-per-secon } \\
\text { d }\end{array}$ & 0 & 0 & 0 \\
\hline
\end{tabular}

Tabel 4

Packet Loss Bonding

\begin{tabular}{|c|c|c|c|c|c|c|}
\hline $\begin{array}{c}\text { Percob } \\
\text { aan } \\
\text { Ke }\end{array}$ & $\begin{array}{c}\text { Pac } \\
\text { ket } \\
\text { Sen } \\
\text { d }\end{array}$ & $\begin{array}{c}\text { Pack } \\
\text { et } \\
\text { Recei } \\
\text { ver }\end{array}$ & $\begin{array}{c}\text { Pac } \\
\text { ket } \\
\text { Los } \\
\text { s }\end{array}$ & $\begin{array}{c}\mathrm{Ti} \\
\mathrm{me} \\
\mathrm{Min}\end{array}$ & $\begin{array}{c}\mathrm{Ti} \\
\mathrm{me} \\
\mathrm{Ma} \\
\mathrm{x}\end{array}$ & $\begin{array}{c}\text { Time } \\
\text { Aver } \\
\text { age }\end{array}$ \\
\hline 1 & 55 & 55 & 0 & $\begin{array}{c}\mathrm{m} \\
\mathrm{s}\end{array}$ & $\begin{array}{c}1 \mathrm{~m} \\
\mathrm{~s}\end{array}$ & $0 \mathrm{~ms}$ \\
\hline 2 & 67 & 67 & 0 & $\begin{array}{c}1 \mathrm{~m} \\
\mathrm{~s}\end{array}$ & $\begin{array}{c}1 \mathrm{~m} \\
\mathrm{~s}\end{array}$ & $0 \mathrm{~ms}$ \\
\hline 3 & 82 & 82 & 0 & $\begin{array}{c}0 \mathrm{~m} \\
\mathrm{~s}\end{array}$ & $\begin{array}{c}1 \mathrm{~m} \\
\mathrm{~s}\end{array}$ & Oms \\
\hline 4 & 126 & 126 & 0 & $\begin{array}{c}0 \mathrm{~m} \\
\mathrm{~s}\end{array}$ & $\begin{array}{c}1 \mathrm{~m} \\
\mathrm{~s}\end{array}$ & Oms \\
\hline 5 & 137 & 137 & 0 & $\begin{array}{c}0 \mathrm{~m} \\
\mathrm{~s}\end{array}$ & $\begin{array}{c}1 \mathrm{~m} \\
\mathrm{~s}\end{array}$ & Oms \\
\hline
\end{tabular}




\begin{tabular}{|c|c|c|c|c|c|c|}
\hline 6 & 143 & 143 & 0 & $\begin{array}{c}1 \mathrm{~m} \\
\mathrm{~s}\end{array}$ & $\begin{array}{c}1 \mathrm{~m} \\
\mathrm{~s}\end{array}$ & $0 \mathrm{~ms}$ \\
\hline 7 & 213 & 213 & 0 & $\begin{array}{c}1 \mathrm{~m} \\
\mathrm{~s}\end{array}$ & $\begin{array}{c}1 \mathrm{~m} \\
\mathrm{~s}\end{array}$ & $0 \mathrm{~ms}$ \\
\hline 8 & 227 & 227 & 0 & $\begin{array}{c}0 \mathrm{~m} \\
\mathrm{~s}\end{array}$ & $\begin{array}{c}1 \mathrm{~m} \\
\mathrm{~s}\end{array}$ & $0 \mathrm{~ms}$ \\
\hline 9 & 241 & 241 & 0 & $\begin{array}{c}0 \mathrm{~m} \\
\mathrm{~s}\end{array}$ & $\begin{array}{c}1 \mathrm{~m} \\
\mathrm{~s}\end{array}$ & $0 \mathrm{~ms}$ \\
\hline 10 & 272 & 272 & 0 & $\begin{array}{c}1 \mathrm{~m} \\
\mathrm{~s}\end{array}$ & $\begin{array}{c}1 \mathrm{~m} \\
\mathrm{~s}\end{array}$ & $0 \mathrm{~ms}$ \\
\hline
\end{tabular}

It can be seen in table 4 that the results of the Link Aggregation network connectivity test when a link failure occurs at one of the interfaces that make up the Link Aggregation. Link Aggregation is able to maintain the quality of its network services by ensuring that there is no packet loss in the bonding network during a failover.

\section{Conclusion}

1. The implementation of Link Aggregation is able to improve a network service, especially in the process of transferring data packets many times more than before.

2. Link aggregation is able to overcome the overload in an interface which can cause link failure. And when the failover process occurs, there is no packet loss on the network.

3. Load balancing in link aggregation can share the network load equally based on the number of interfaces used

\section{References}

[1] Samuel and C. E. Samudera, "Rancang Bangun Mekanisme Load Sharing Pada Link Aggregation Menggunakan Software Defined Networking," Ultim. Comput., vol. IX, no. 1, pp. 41-47, 2017.

[2] R. Rulloh, "Analisis Rerformansi Agregasi Link Dengan LACP Pada Sdn Menggunakan Ryu Sebagai Controller," j. nas. tek. elektro, vol. 6, no. 3, pp. 204-213, 2017.

[3] M. A. S. Arifin, "Analisis Peningkatan Troughput Bandwidth Menggunakan Link Aggregation Untuk Jaringan Point To Point," J. Teknol. Inf. MURA, vol. 9, no. 2, pp. 108-115, 2017.

[4] D. A. Cahyadi, R. Efendi, and F. N. Hakim, "Optimalisasi Throughput Menggunakan Link Aggregation Berbasis Open Source (Studi Kasus: PT Selaras Eka Citra Pariwara)," J. Transform., vol. 12, no. 2, pp. 53-61, 2015.

[5] L. Bruckman, G. Mor, and Z. Menahemi, "Bandwidth Allocation For Link Aggregation," 2008.

[6] S. Chikkamath, P. Thayalan, and M. Raman, "Redundent Virtual Link Aggregation Group," 2019.

[7] S. RAVINOOTHALA, "Managing Link Aggregation Traffic In Edge Nodes," 2018.

[8] S. Hanadwiputra and Subandr, "Analisa Dan Implementasi Vtp Dengan 
Etherchannel Type LACP," J. KILAT, vol. 7, no. 1, pp. 78-85, 2018.

[9] T. Sukendar and M. I. Saputro, "Analisa Jaringan Lan Menggunakan Teknologi Etherchannel Untuk Meningkatkan Performa Jaringan Pada Smu Panca Sakti Jakarta," J. Teknol. Inf., vol. 5, no. 2, pp. 2-9, 2019.

[10] K. Nugroho and M. S. Fallah, "Implementasi Load Balancing Menggunakan Teknologi Etherchannel Pada Jaringan LAN," ELKOMIKA, vol. 6, no. 3, pp. 420-435, 2018.

[11] Z. Amin, "Simulasi Dan Perancangan Keamanan Autentikasi Jaringan Hirarki Link Aggregation Control Protocol (LACP) Berbasis Router Cisco (Studi Kasus : Stmik Palcomtech) Zaid," in Konfrensi Nasional Tekhnologi Informasi dan Aplikasinya Palembang, 2014, no. September, pp. 9-17.

[12] Y. Widiyanto, R. M. Negara, and T. R. Gading, "Implementasi Algoritma Self-Tuned Adaptive Routing Dan Link Aggregation Group Untuk Mencegah Congestion Pada Software Defined Network Nokia," in ISSN : 2355-9365 e-Proceeding of Engineering :, 2018, vol. 5, no. 3, pp. 4942-4949.

[13] K. M. Rifaldi, Suroso, and E. Susanti, "Analisis Trafik Jaringan Yang Implementasi Link Aggregation Pada Metro Ethernet di PT. Telekomunikasi Indonesia Witel SumSel," in Prosiding SNATI F Ke-4, 2017, pp. 389-394.

[14] T. Graf and J. Pirko, "Link-Layer Level Linkaggregation Autoconfiguration," 2016.

[15] Febriyanto, E., Naufal, R. S., \& budiarty, frizca. (2019). Attitude Competency Assessment in the 2013 curriculum based on elementary school Prototyping methods. IAIC Transactions on Sustainable Digital Innovation (ITSDI), 1(1), 87-96. https://doi.org/10.34306/itsdi.v1i1.6

[16] 2. Sunarya, P. A., Aini, Q., Bein, A. S., \& Nursaputri, P. (2019). The Implementation Of Viewboard Of The Head Of Department As A Media For Student Information Is Worth Doing Final Research. ITSDI Journal Edition Vol. 1 No. 1 October 2019, 18.

[17] 3. Febriyanto, E., \& Naufal, R. S. (2019). Attitude Competency Assessment in the 2013 Curriculum Based On Elementary School Prototyping Methods. IAIC Transactions on Sustainable Digital Innovation, 1(1), 87-96.

[18] 4. Yusup, M., Aini, Q., Apriani, D., \& Nursaputri, P. (2019, December). PEMANFAATAN TEKNOLOGI BLOCKCHAIN PADA PROGRAM SERTIFIKASI DOSEN. In SENSITIf: Seminar Nasional Sistem Informasi dan Teknologi Informasi (pp. 365-371)

[19] 5. Rao, S. S., \& Siddaiah, P. (2020). Design of Eight-Phase Sequences using Modified Particle Swarm Optimization for Spread Spectrum and Radar Applications. APTIKOM Journal on Computer Science and Information Technologies, 6(1), 30-40. https://doi.org/10.34306/csit.v6i1.368

[20] 6. S, S., T, R., \& SP, S. (2020). An optimized Rubber Sheet Model for Normalization Phase of IRIS Recognition. APTIKOM Journal on Computer Science and Information Technologies, 6(1), 20-29. https://doi.org/10.34306/csit.v6i1.356 